\title{
Kepatuhan Terhadap Pengobatan Pasien Diabetes Melitus Tipe 2 di Puskesmas Jakarta Timur
}

\section{(The Compliance On Their Medication Of Type 2 Diabetes Mellitus Patients In The Public Health Center In East Jakarta)}

\author{
Rizki Romadhon $^{1}$, Yardi Saibi ${ }^{1 *}$, Narila Mutia Nasir ${ }^{1}$ \\ ${ }^{1 *}$ Fakultas Ilmu Kesehatan, Universitas Islam Negeri Syarif Hidayatullah Jakarta. \\ E-mail:yardi@uinjkt.ac.id \\ Article Info: \\ Received: 29 januari 2020 \\ in revised form: 15 Februari 2020 \\ Accepted: 26 Februari 2020 \\ Available Online: 02 Maret 2020

\section{Keywords:} \\ Diabetic Melitus type 2 \\ Compliance Level \\ Incompliance \\ Blood Glucose Test Result \\ MMAS-8 \\ Corresponding Author: \\ Yardi Saibi \\ Fakultas Ilmu Kesehatan \\ Universitas Islam Negeri Syarif \\ Hidayatullah \\ Jakarta \\ 15412 \\ Indonesia \\ email:yardi@uinjkt.ac.id

\begin{abstract}
The highest prevalence of diabetes mellitus based on Basic Health Research in Indonesia is in the province of DKI Jakarta. Unadherence with treatment of type 2 diabetes mellitus patients is one of the factors that results in low blood glucose control and an increased risk of complications. This study was conducted to determine the profile of drug use adherence levels in the Makasar Public Health Center in East Jakarta and the factors that influence drug use adherence in patients with type 2 diabetes mellitus. This cross sectional design study was conducted in April 2019 to June 2019 with a total of 175 diabetic melitus type 2 respondents. Data collection was carried out using a structured interview technique using the MMAS-8 adherence questionnaire. Data were processed using statistical software and analyzed using frequency distribution analysis and chi square test. The results showed that 71 respondents $(40.6 \%)$ had a moderate level of compliance using antidiabetic drugs. The main reason for unadherence was boredom (43.6\%). There is a significant relationship between the level of adherence and blood sugar test results. To find out more about the relationship between the level of adherence with blood sugar test results it is necessary to have further research on the relationship of blood sugar test results with adherence prospectively.
\end{abstract}

Copyright $\odot 2019$ JFG-UNTAD

This open access article is distributed under a Creative Commons Attribution (CC-BY-NC-SA) 4.0 International license.

How to cite (APA $6^{\text {th }}$ Style):

Romadhon, R., Saibi, Y., Nasir, N. M. (2020). Kepatuhan Terhadap Pengobatan Pasien Diabetes Melitus Tipe 2 di Puskesmas Jakarta Timur. Jurnal Farmasi Galenika: Galenika Journal of Pharmacy, 6(1), 94-103. doi:10.22487/j24428744.2020.v6.i1.15002 


\section{ABSTRAK}

Prevalensi diabetes melitus berdasarkan hasil Riset Kesehatan Dasar yang tertinggi di Indonesia terdapat di provinsi DKI Jakarta. Ketidakpatuhan berobat pasien diabetes melitus tipe 2 merupakan salah satu faktor yang mengakibatkan rendahnya kontrol gula darah dan meningkatnya resiko komplikasi. Penelitian ini dilakukan untuk mengetahui profil tingkat kepatuhan penggunaan obat di Puskesmas Kecamatan Makasar Jakarta Timur dan faktor-faktor yang mempengaruhi kepatuhan penggunaan obat pada pasien diabetes melitus tipe 2. Penelitian ini berdesain cross sectional yang dilaksanakan pada April 2019 sampai Juni 2019 dengan total 175 responden diabetes melitus tipe 2. Pengumpulan data dilakukan dengan teknik wawancara terstruktur menggunakan kuesioner kepatuhan MMAS-8. Data diolah dengan menggunakan software statistik dan dianalisa menggunakan analisa distribusi frekuensi dan uji chi square. Hasil penelitian menunjukkan bahwa 71 responden $(40,6 \%)$ memiliki tingkat kepatuhan sedang dalam menggunakan obat antidiabetes. Alasan utama ketidakpatuhan responden adalah bosan $(43,6 \%)$. Ada hubungan bermakna antara tingkat kepatuhan dan kadar gula darah. Untuk mengetahui lebih dalam hubungan antara tingkat kepatuhan dengan kadar gula darah maka perlu adanya penelitian lanjutan tentang hubungan kadar gula darah dengan tingkat kepatuhan secara prospektif

Kata kunci: Diabetes Melitus Tipe 2, Tingkat Kepatuhan, Ketidakpatuhan, Kadar gula darah, MMAS-8.

\section{PENDAHULUAN}

Kepatuhan pengobatan adalah sejauh mana perilaku seseorang minum obat, mengikuti diet, dan / atau menjalankan perubahan gaya hidup, sesuai dengan rekomendasi yang disepakati dari penyedia layanan kesehatan (World Health Organiation, 2003). Kepatuhan merupakan salah satu faktor yang sangat penting dalam keberhasilan terapi seorang pasien termasuk pasien diabetes melitus tipe 2 (DM tipe 2). Kepatuhan menjadi persoalan yang perlu mendapat perhatian pada pasien DM tipe 2. Berbagai penelitian melaporkan rendahnya kepatuhan pada pasien tersebut. Penelitian yang dilakukan di Puskesmas Wilayah Surabaya Timur menyebutkan bahwa kepatuhan terhadap penggunaan obat oleh pasien DM tipe 2 dengan kategori tidak patuh sebesar 54,35\% tidak patuh (Nafi'ah, 2015). Penelitian lain menemukan hanya 39,6\% pasien yang patuh menggunakan obat dan menebus obat dan alasan terbanyak ketidakpatuhan adalah terlambat menebus obat $(86,4 \%)$ dan lupa minum obat $(77,3 \%)$ (Srikartika, Cahya, Suci, Hardiati, \& Srikartika, 2016). Penelitian yang dilakukan di Instalasi Rawat Jalan Rumah Sakit Umum Daerah Ulin Banjarmasin menemukan bahwa responden yang patuh terhadap terapi sebanyak $43,6 \%$ sedangkan yang lain dianggap tidak patuh. Selain itu tingkat keberhasilan terapi responden sebesar 35,9\% sedangkan sisanya yaitu sebesar $64,1 \%$ dikatakan terapinya tidak berhasil (Mulyani, 2016).

Prevalensi DM tipe 2 di Indonesia berdasarkan wawancara yang terdiagnosis dokter sebesar $2 \%$, hal ini mengalami peningkatan dari tahun 2013 sebesar 0,5\%. Prevalensi tertinggi pertama terdapat di DKI Jakarta sebesar 3,4\%, hal ini mengalami peningkatan dari tahun 2013 sebesar 0,9\%. Prevalensi pada perempuan cenderung lebih tinggi dari pada laki-laki. Prevalensi Diabetes Melitus di perkotaan cenderung lebih tinggi dari pada perdesaan. Prevalensi diabetes melitus cenderung lebih tinggi pada masyarakat dengan tingkat pendidikan tinggi dan dengan kuintil indeks kepemilikan tinggi (Kementerian Kesehatan RI, 2018).

Puskesmas merupakan bentuk pelayanan dan fasilitas kesehatan yang penting dan terjangkau bagi seluruh kalangan masyarakat, khususnya bagi masyarakat ekonomi menengah ke bawah. Faktor biaya periksa dan obat yang lebih murah, serta lokasinya yang mudah dijangkau (berada di tiap kelurahan ataupun kecamatan) merupakan alasan utama masyarakat memilih Puskesmas sebagai tempat untuk berobat(Radito, 2014). Data dari suku dinas kesehatan Jakarta Timur menunjukkan bahwa jumlah pasien DM tipe 2 yang berobat di puskesmas kecamatan Makasar Jakarta Timur tahun 2018 merupakan yang terbanyak diantara kecamatan lainnya. Penelitian ini bertujuan untuk melihat kepatuhan pasien DM tipe 2 yang sedang melakukan pengobatan di puskesmas kecamatan Makasar Jakarta Timur. 


\section{METODE PENELITIAN}

Penelitian ini berdesain cross sectional. Penelitian dilakukan di Puskesmas Kecamatan Makasar Jakarta Timur periode April - Juni 2019 dengan populasi seluruh pasien DM tipe 2 yang berobat rawat jalan di puskesmas tersebut periode April - Juni 2019. Sampel terdiri dari 175 pasien rawat jalan yang telah terdiagnosa DM tipe 2 yang memenuhi kriteria inklusi dan eksklusi. Kriteria Inklusi yaitu pasien dengan diagnosis DM tipe 2 yang berobat rawat jalan di Puskesmas Kecamatan Makasar Jakarta Timur periode April 2019 - Juni 2019, pasien bersedia berpartisipasi dalam penelitian, menerima resep obat antidiabetes dan menjalani pengobatan minimal selama 4 bulan. Penelitian ini dilakukan dengan meminta izin penelitian dan pengambilan data dari Suku Dinas Kesehatan Kota Jakarta Timur dan Puskesmas Kecamatan Makasar Kota Jakarta Timur. Kajian etik penelitian didapatkan dari Komite Etik Penelitian Kesehatan Fakultas Kedokteran Universitas Indonesia.Teknik pengambilan sampel dalam penelitian ini adalah purposive sampling dengan jumlah sampel minimal yang dibutuhkan adalah 97 responden. Instrumen yang digunakan untuk pengumpulan data adalah kuesioner kepatuhan penggunaan obat MMAS-8 yang telah tervalidasi dan profil data alasan ketidakpatuhan(Morisky, Ang, Krousel-Wood, \& Ward, 2008). Disamping itu juga dikumpulkan profil data karakteristik responden, profil data regimen terapi farmakologi responden dan profil data kadar gula darah responden. Validitas dan reabilitas kuesioner MMAS-8 diujikan kepada 30 responden. Berdasarkan hasil uji validitas kuesioner MMAS-8 diperoleh hasil bahwa untuk item 1 sampai 8 memiliki nilai $\mathrm{R}_{\text {hitung }}$ lebih besar dari $\mathrm{R}_{\text {tabel }}\left(\mathrm{R}_{\text {hitung }}>0,361\right)$. Maka dapat disimpulkan bahwa kuesioner MMAS-8 yang terdiri dari 8 item pertanyaan adalah semuanya valid. Uji reliabilitas dilakukan untuk mengetahui apakah indikator yang digunakan dapat dipercaya sebagai alat ukur variable. Indikator dinyatakan reliabel apabila nilai cronbach's alpha $(\alpha)$ yang diperoleh $>0,6$. Berdasarkan nilai Reliability Statistic kuesioner MMAS-8 yang terdiri dari 8 item pertanyaan menunjukkan bahwa nilai Cronbach's Alpha sebesar 0,703 > 0,6. Maka dapat disimpulkan bahwa item pada instrumen sudah reliable (konsisten) dan dengan demikian kuesioner dapat digunakan untuk mengumpulkan data yang diperlukan. Data responden yang diperoleh kemudian diolah dengan menggunakan software statistik dan dianalisa menggunakan analisa distribusi frekuensi dan uji chi square.

\section{HASIL DAN PEMBAHASAN}

Tabel 1 Karakteristik responden

\begin{tabular}{llcc}
\hline No & Karakteristik & $\begin{array}{c}\text { Jumlah } \\
\text { (Orang) }\end{array}$ & $\begin{array}{c}\text { Persentase } \\
(\%)\end{array}$ \\
\hline & Jenis Kelamin & 63 & 36 \\
1 & Laki-laki & 112 & 64 \\
2 & Perempuan & & \\
& Tingkat Pendidikan Terakhir & 11 & 6,3 \\
1 & Tidak Sekolah & 39 & 22,3 \\
2 & SD/ Sederajat & 36 & 20,6 \\
3 & SMP/ Sederajat & 64 & 36,6 \\
4 & SMA/ Sederajat & 12 & 6,9 \\
5 & D1/ D2/ D3/ D4 & 13 & 7,4 \\
6 & S1/ S2/ S3 & 1 & 0,6 \\
& Umur & 26 & 14,9 \\
1 & 21- 35 tahun & 32 & 18,3 \\
2 & 36- 50 tahun & 116 & 66,3 \\
3 & 51- 59 tahun & & \\
4 & $\geq$ 60 tahun & 34 & 19,4 \\
& Pekerjaan & &
\end{tabular}




\begin{tabular}{|c|c|c|c|}
\hline 2 & Ibu Rumah Tangga & 94 & 53,7 \\
\hline 3 & Karyawan Swasta & 8 & 4,6 \\
\hline 4 & Wiraswasta & 5 & 2,9 \\
\hline 5 & Pensiunan PNS & 31 & 17,7 \\
\hline \multirow[t]{2}{*}{6} & PNS/ TNI/ POLRI & 3 & 1,7 \\
\hline & Lama Menderita & & \\
\hline 1 & $>10$ tahun & 54 & 30,9 \\
\hline 2 & 6- 10 tahun & 25 & 14,3 \\
\hline \multirow[t]{2}{*}{3} & $<6$ tahun & 96 & 54,9 \\
\hline & Riwayat Penyakit Keturunan & & \\
\hline 1 & Kakek & 2 & 1,1 \\
\hline 2 & Bapak & 21 & 12 \\
\hline 3 & $\mathrm{Ibu}$ & 29 & 16,6 \\
\hline 4 & Paman & 5 & 2,9 \\
\hline 5 & Bibi & 4 & 2,3 \\
\hline 6 & Saudara Kandung & 13 & 7,4 \\
\hline \multirow[t]{2}{*}{7} & Tidak Ada & 101 & 57,7 \\
\hline & Penyakit penyerta & & \\
\hline 1 & Penyakit Jantung & 8 & 4,6 \\
\hline 2 & Stroke & 4 & 2,3 \\
\hline 3 & Gagal Ginjal Kronis & 1 & 0,6 \\
\hline 4 & Gangguan Penglihatan & 11 & 6,3 \\
\hline 5 & Hipertensi & 79 & 45,1 \\
\hline 6 & Luka dan Infeksi pada Kaki & 1 & 0,6 \\
\hline 7 & Kerusakan Kulit & 3 & 1,7 \\
\hline 8 & Lain-lain & 16 & 9,1 \\
\hline \multirow[t]{2}{*}{9} & Tidak Ada & 52 & 29,7 \\
\hline & Frekuensi penggunaan obat & & \\
\hline 1 & $1 \times 1$ & 31 & 17,7 \\
\hline 2 & $2 \times 1$ & 45 & 25,7 \\
\hline \multirow[t]{2}{*}{3} & $3 \times 1$ & 99 & 56,6 \\
\hline & Total & 175 & 100 \\
\hline
\end{tabular}

Dapat dilihat pada tabel karakteristik responden bahwa $64 \%$ berjenis kelamin perempuan, dengan kategori tingkat pendidikan terbesar adalah SMA sederajat. Usia lebih atau sama dengan 60 tahun mendominasi jumlah responden yakni sebanyak 66,3\%. Pekerjaan responden terbesar adalah ibu rumah tangga sebesar 53,7\%. Lima puluh tujuh koma tujuh persen responden mengalami penyakit DM tipe 2 tanpa disebabkan oleh riwayat keturunan dan penyakit penyerta terbanyak yang dialami oleh pasien adalah hipertensi sebesar 45,1\%. Temuan dari penelitian ini terkait faktor demografi pasien DM tipe 2 sejalan dengan beberapa penelitian sebelumnya. Penelitian yang dilakukan di RS Kota Banjarbaru menunjukkan bahwa penyakit diabetes melitus sebagian besar dijumpai pada responden yang berjenis kelamin perempuan dibandingkan responden yang berjenis kelamin laki-laki(Srikartika et al., 2016). Hasil ini juga selaras dengan hasil RISKESDAS 2018 yang menyatakan prevalensi diabetes melitus berdasarkan diagnosis dokter lebih banyak pada penderita yang berjenis kelamin perempuan $(1,8 \%)$ dibandingkan penderita yang berjenis kelamin laki-laki $(1,2 \%)$ (Kementerian Kesehatan RI, 2018). Beberapa faktor yang diduga menjadi penyebab wanita lebih berisiko terkena DM tipe 2 antara lain: perempuan cenderung mengalami resiko stres yang cukup meningkat sehingga dapat memicu kenaikan kadar gula darah; riwayat kehamilan; obesitas; penggunaan kontrasepsi oral dan tingkat stres yang cukup tinggi(Willer, Herreiter, \& Pacini, 2016).

Hasil inipun sejalan dengan data Kementerian Kesehatan yang menyatakan prevalensi diabetes melitus berdasarkan diagnosis dokter lebih banyak pada penderita yang berumur $\geq 60$ tahun $(12,45 \%)$ 
(Kementerian Kesehatan RI, 2018). Intoleransi glukosa terganggu dikaitkan dengan penuaan dan hiperglikemia postprandial adalah karakteristik yang menonjol dari diabetes tipe 2 pada orang dewasa yang lebih tua. Resistensi insulin yang berhubungan dengan usia dikaitkan dengan perubahan komposisi tubuh dan aktivitas fisik(Kalyani, Golden, \& Cefalu, 2017).

Penelitian yang dilakukan Srikartika di RS Kota Banjarbaru menunjukkan bahwa responden yang terdiagnosis diabetes melitus sebagian besar memiliki penyakit penyerta (Srikartika et al., 2016). Temuan serupa juga dilaporkan pada penelitian yang dilakukan di puskesmas wilayah Surabaya Timur yang memaparkan bahwa pasien diabetes melitus sebagian besar mengalami gangguan kesehatan lainnya(Nyoman Wijaya et al., 2015). Penyakit penyerta terbanyak adalah hipertensi. Diabetes melitus dan dan hipertensi memiliki beberapa mekanisme patofisiologis yang sama, yakni: aktivasi sistem renin angiotensin aldosteron yang tidak memadai; stres oksidatif akibat produksi berlebihan spesies oksigen reaktif; peradangan; gangguan vasodilatasi yang dimediasi insulin; peningkatan aktivasi sistem saraf simpatis; disfungsi respon sistem imun adaptif dan bawaan penanganan natrium ginjal yang abnormal . Obesitas dan peningkatan adipositas visceral merupakan faktor patogenisitas utama di balik koeksistensi diabetes melitus dan hipertensi. Peradangan kronis tingkat rendah dan stres oksidatif dalam jaringan adiposa menyebabkan peningkatan produksi angiotensinogen dan angiotensin II yang mengakibatkan aktivasi jaringan (Lastra, Syed, Kurukulasuriya, Manrique, \& Sowers, 2014).

Tingkat kepatuhan pasien DM tipe 2 yang tengah mendapatkan pengobatan dapat dilihat pada tabel 2 berikut.

Tabel 2 Profil Distribusi frekuensi tingkat kepatuhan.

\begin{tabular}{llcc}
\hline No & Tingkat Kepatuhan & Jumlah (Orang) & Persentase (\%) \\
\hline 1 & Kepatuhan Tinggi & 65 & 37,1 \\
2 & Kepatuhan Sedang & 71 & 40,6 \\
3 & Kepatuhan Rendah & 39 & 22,3 \\
& Total & 175 & 100 \\
\hline
\end{tabular}

Berdasarkan tabel 2 di atas dapat diketahui bahwa 71 responden (40,6\%) memiliki tingkat kepatuhan sedang dalam menggunakan obat antidiabetes, sedangkan 65 responden $(37,1 \%)$ memiliki tingkat kepatuhan tinggi dan sisanya sebesar 39 responden (22,3) memiliki tingkat kepatuhan rendah. Perbedaan jumlah berdasarkan tingkat kepatuhan ini sejalan dengan hasil penelitian yang dilakukan di RSUD Ulin Banjarmasin bahwa sebagian besar responden termasuk dalam kategori tidak patuh dibandingkan responden yang termasuk dalam kategori patuh. Dari 39 responden sebagian besar responden termasuk dalam kategori tidak patuh yaitu sebanyak 22 responden $(56,4 \%)$ dan sisanya sebanyak 17 responden (43,6\%) termasuk dalam kategori patuh(Mulyani, 2016). Penelitin yang dilakukan di Saudi Arabia juga menemukan bahwa tingkat kepatuhan minum obat antidiabetes dengan kategori kepatuhan rendah cukup banyak yakni sebesar 42,8\%(Balkhi et al., 2019). Tingkat kepatuhan yang cukup tinggi dijumpai pada penelitian yang dilakukan di sebuah rumah sakit di Ibadan, Nigeria yang menemukan bahwa 60 persen pasien memiliki kepatuhan yang tingggi terhadap pengobatnnya. Begitu pula dengan penelitian yang dilakukan di Puskesmas Kedung Kandang Malang yang menemukan bahwa 83,3\% pasien diabetes melitus patuh terhadap pengobatan yang sedang mereka jalani (Adisa, Fakeye, \& Fasanmade, 2011; Hidajah R, 2012).

Kepatuhan merupakan salah satu faktor penentu dari keberhasilan terapi pasien disamping faktor lainnya seperti ketepatan dalam pemilihan obat, ketepatan regimen pengobatan serta dukungan gaya hidup yang sehat dari pasien. Ketidakpatuhan dapat menyebabkan pasien kehilangan manfaat terapi dan kemungkinan mengakibatkan kondisi secara bertahap memburuk. Dalam kaitan dengan terapi DM tipe 2, ketidakpatuhan pasien dalam menjalani pengobatanya dapat menyebabkan kegagalan dalam pengontrolan kadar gula darah mereka dan jika kondisi ini berlangsung lama, dapat mengarah timbulnya komplikasi penyakit baik komplikasi makrovaskuler maupun mikrovaskuler (Chawla, 
Chawla, \& Jaggi, 2016). Peran tenaga kesehatan dalam meningkatkan kepatuhan pasien sangat diperlukan. Salah satu tenaga kesehatan yang diharapkan perannya adalah tenaga kefarmasian terutama apoteker. Edukasi penting diberikan pada pasien terutama yang mendapatkan terapi jangka panjang seperti DM tipe 2 (Kementerian Kesehatan RI, 2016). Apoteker sebagai tenaga kesehatan yang bertanggung jawab pada pengobatan pasien dapat berpartisipasi aktif untuk membantu meningkatkan kepatuhan pasien dalam menggunakan obat seperti : mengadakan promosi kesehatan (memberikan brosur, pamflet agar pasien memahami penyakit dan pengobatannya sehingga turut berperan dalam menjaga kesehatan); memberikan alat bantu seperti kalender pengobatan dan kartu pengingat menggunakan obat yang dapat ditandai bila pasien sudah menggunakan obat; memberikan informasi tambahan atau tulisan yang besar dan jelas pada etiket obat untuk pasien yang sulit mendengar atau melihat; serta memberikan dukungan, motivasi, serta memberikan kemudahan dalam upaya pengobatan. Keterlibatan apoteker sebagai tenaga kesehatan di bidang kefarmasian dalam pengobatan pasien baik melalui pemberian konseling, pemberian informasi obat telah dilaporkan dalam beberapa publikasi dapat meningkatkan kepatuhan pasien dalam menggunakan obat mereka (Alajmi, Al-Aqeel, \& Baz, 2017; Cohen et al., 2013; Dewanti, Andrajati, \& Supardi, 2015; Neswita, Almasdy, \& Harisman, 2016).

Tabel 3 Distribusi frekuensi item kuesioner kepatuhan MMAS-8

\begin{tabular}{|c|c|c|c|c|}
\hline No & Pernyataan & Jawaban & $\mathbf{n}$ & $\%$ \\
\hline 1. & $\begin{array}{l}\text { Lupa minum/ menyuntikkan obat } \\
\text { antidiabetes }\end{array}$ & Ya & 79 & 45,1 \\
\hline 2. & $\begin{array}{l}\text { Tidak minum/ menyuntikkan obat } \\
\text { antidiabetes selama } 2 \text { minggu terakhir }\end{array}$ & Ya & 54 & 30,9 \\
\hline 3. & $\begin{array}{l}\text { Mengurangi atau berhenti minum/ } \\
\text { menyuntikkan obat antidiabetes tanpa } \\
\text { memberi tahu dokter karena merasa lebih } \\
\text { buruk ketika minum/ menyuntikkannya }\end{array}$ & Ya & 13 & 7,4 \\
\hline 4. & $\begin{array}{l}\text { Lupa membawa obat ketika bepergian atau } \\
\text { meninggalkan rumah }\end{array}$ & Ya & 39 & 22,3 \\
\hline 5. & $\begin{array}{l}\text { Kemarin minum/ menyuntikkan obat } \\
\text { antidiabetes }\end{array}$ & Ya & 155 & 88,6 \\
\hline 6. & $\begin{array}{l}\text { Kadang-kadang menghentikan/ tidak } \\
\text { menggunakan obat antidiabetes jika merasa } \\
\text { kondisi lebih baik }\end{array}$ & Ya & 18 & 10,3 \\
\hline 7. & $\begin{array}{l}\text { Terganggu dalam mematuhi pengobatan } \\
\text { setiap hari }\end{array}$ & Ya & 18 & 10,3 \\
\hline \multirow{5}{*}{8.} & \multirow{5}{*}{$\begin{array}{l}\text { Kesulitan dalam mengingat penggunaan } \\
\text { obat }\end{array}$} & Sangat Jarang/Tidak pernah & 169 & 96,6 \\
\hline & & Kadang-kadang & 3 & 1,7 \\
\hline & & Sering/Selalu & 1 & 0,6 \\
\hline & & Sesekali & 1 & 0,6 \\
\hline & & Biasanya & 1 & 0,6 \\
\hline
\end{tabular}

Tabel 3 memaparkan jumlah responden yang memberikan jawaban "ya" terhadap pertanyaan yang terdapat di dalam kuesioner MMAS. Beberapa masalah yang menyebabkan ketidakpatuhan responden yang paling banyak adalah responden lupa minum/ menyuntikkan obat antidiabetes sebesar $(45,1 \%)$. Dominasi jumlah responden yang berumur $\geq 60$ tahun ini mungkin memiliki keterkaitan dengan kelupaan responden dalam meminum obat. Hal tersebut didukung dengan proses degenerasi organorgan tubuh manusia, salah satunya penurunan memori (Small, 2001). Karena itu lupa minum obat pada lansia merupakan keluhan yang sering disampaikan oleh mereka. 
Terhadap 110 orang responden yang masuk dalam kategori tingkat kepatuhan sedang dan rendah yakni sebanyak 110 orang ditanyakan beberapa pertanyaan. Pertanyaan tersebut diajukan untuk menggali penyebab ketidakpatuhan mereka. Hasilnya disajikan di dalam tabel 4. Dapat diketahui bahwa 48 responden $(43,6 \%)$ beralasan merasa bosan jika rutin menggunakan obat antidiabetes dalam jangka waktu yang lama bahkan seumur hidup. Dua puluh tujuh responden $(24,5 \%)$ beralasan terlambat menebus obat jika obat sudah habis dikarenakan malasnya responden untuk kembali rutin berobat rawat jalan lagi di puskesmas. Keterbatasan puskesmas yang hanya bisa menyediakan obat dalam jangka waktu paling lama 2 minggu. 26 responden $(23,6 \%)$ beralasan tidak ada yang mengingatkan untuk menggunakan obat dikarenakan rendahnya rasa peduli dan perhatian anggota keluarga terhadap responden. Hal ini bertolak belakang dengan status responden yang semuanya sudah menikah dan rata-rata sudah mempunyai anak. Sebagian kecil responden beralasan tidak paham cara menggunakan obat seperti obat insulin injeksi. Insulin dalam bentuk sediaan injeksi memberikan rasa tidak nyaman pada responden karena harus disuntikkan setiap hari dan beralasan padatnya aktivitas jam kerja. Alasan lain responden tidak menggunakan obat antidiabetes yaitu : karena ketiduran sebelum menggunakan obat pada malam hari; takutnya menggunakan obat insulin injeksi ; dan takut efek ketergantungan dari obat serta malas untuk rutin menggunakan obat setiap hari.

Tabel 4 Profil Distribusi frekuensi alasan ketidakpatuhan.

\begin{tabular}{llcc}
\hline No & Alasan Ketidakpatuhan & Jumlah (Orang) & Persentase (\%) \\
\hline 1 & Terlambat menebus obat & 27 & 24,5 \\
2 & Tidak paham cara & 3 & 2,7 \\
& penggunaan obat & & \\
3 & Aktivitas yang padat & 3 & 2,7 \\
4 & Bosan & 48 & 43,6 \\
5 & Tidak ada PMO & 26 & 23,6 \\
6 & Lain-lain & 3 & 2,7 \\
& Total & 110 & 100 \\
\hline
\end{tabular}

Hasil yang sedikit berbeda terkait urutan penyebab ketidakpatuhan ini dilaporkan dalam penelitian yang dilakukan di Puskesmas Daerah Istimewa Yogyakarta dengan urutan sebagai berikut : aktivitas yang padat $(46,6 \%)$; obat habis $(14,8 \%)$; lupa mengonsumsi obat $(13,6 \%)$; lupa karena ketiduran; obat tertinggal; tidak ada yang mengingatkan; serta sulit untuk membedakan apakah sudah meminum obat atau belum (Rasdianah, Martodiharjo, Andayani, \& Hakim, 2016). Untuk meningkatkan kemampuan pasien dalam mengikuti aturan pengobatan, perlu dilakukan berbagai upaya terhadap pasien. Diantara upaya yang dapat dilakukan untuk mencapai tujuan ini antara lain : menelpon pasien atau kunjungan ke rumah sebagai bentuk follow up setelah pemberian obat kepada mereka oleh apoteker; pemberian edukasi kepada pasien terkait dengan bagaimana cara menggunakan obat dengan benar dan juga edukasi terkait penyakit yang sedang dideritanya(Costa et al., 2015)

Hubungan antara tingkat kepatuhan dengan pengendalian kadar gula darah disajikan di dalam tabel 5. Tingkat kepatuhan MMAS-8 dikelompokkan kembali menjadi 2 kelompok yakni patuh dan kurang patuh. Kategori patuh adalah kategori kepatuhan tinggi dengan kurang patuh terdiri dari tingkat kepatuhan sedang dan rendah.

Tabel 5 Hubungan tingkat kepatuhan dengan kadar gula darah

\begin{tabular}{lccccccc}
\hline \multirow{2}{*}{ Tingkat Kepatuhan } & \multicolumn{4}{c}{ Kadar gula darah } & \multicolumn{2}{c}{ Total } & \multirow{2}{*}{ p-value } \\
\cline { 2 - 6 } & \multicolumn{2}{c}{ Terkontrol } & \multicolumn{3}{c}{ Tidak Terkontrol } & & \\
\cline { 2 - 6 } & $\mathrm{n}$ & $\%$ & $\mathrm{n}$ & $\%$ & $\mathrm{~N}$ & $\%$ & \\
\hline Patuh & 43 & 24,57 & 22 & 12,57 & 65 & 37,15 & 0,000 \\
Kurang Patuh & 34 & 19,42 & 76 & 43,42 & 110 & 62,85 & \\
Total & 77 & 44 & 98 & 56 & 175 & & \\
\hline
\end{tabular}


Tabel 5 menunjukan hubungan antara tingkat kepatuhan dengan kadar gula darah. Dapat dilihat bahwa pasien dengan dengan kategori patuh memiliki kadar gula darah yang terkontrol dengan jumlah pasien yang lebih banyak jika dibandingkan dengan pasien dengan kategori kurang patuh yakni $24,57 \%$ berbanding 19,42\%. Sementara Pasien kurang patuh memiliki dampak terhadap kadar gulah darah yang tidak terkontrol dengan jumlah yang jauh lebih banyak dibandingkan pasien yang patuh yakni 43,42\% berbanding 12,57\%. Dikatakan terkontrol jika GDS $<200 \mathrm{mg} / \mathrm{dL}$ atau GDP $<126 \mathrm{mg} / \mathrm{dL}$ dan dikatakan tidak terkontrol jika GDS $\geq 200 \mathrm{mg} / \mathrm{dL}$ atau GDP $\geq 126 \mathrm{mg} / \mathrm{dL}$. Berdasarkan hasil uji analisa bivariat antara variabel tes gula darah dengan tingkat kepatuhan didapatkan $p=0,000$ lebih kecil dari $\alpha=0,05$ yang dapat diartikan bahwa ada hubungan bermakna antara tingkat kepatuhan dengan tes gula darah. Tingkat kepatuhan yang tinggi terhadap pengobatan akan berhubungan dengan terkotrol atau tidaknya kadar gula darah pasien. Hasil penelitian ini sejalan dengan penelitian yang dilakukan di Puskesmas Dinoyo Malang yang menunjukkan bahwa ada hubungan bermakna antara kadar gula darah dengan tingkat kepatuhan(Bulu, Wahyuni, \& Sutriningsih, 2019). Berdasarkan hasil penelitian dapat dipahami bahwa tingkat kepatuhan minum obat kategori kurang patuh bisa meningkatkan kadar gula darah menjadi tidak terkontrol pada pasien, sedangkan mereka yang memiliki kepatuhan tinggi akan mampu menjaga kadar gula darah dalam tubuh tetap terkontrol sehingga kualitas hidup pasien tetap terjaga dengan baik. Kepatuhan bukan merupakan satu-satunya faktor penentu keberhasilan terapi. Ada faktor lain yang ikut menentukan, antara lain ketepatan pemilihan obat (rasionalitas obat) serta terapi non farmakologi yang harus ditaati oleh pasien seperti aktifitas fisik dan pola makan. Faktor-faktor selain kepatuhan ini tidak diamati dalam penelitian ini. Sehingga dapat dilihat pada tabel 5 di atas bahwa terdapat pasien yang patuh tetapi kadar gulah darahnya masih tidak terkontrol, begitu pula dengan masih dijumpai pasien yang kurang patuh tetapi kadar gula darahnya tetap terkontrol.

\section{KESIMPULAN}

Tingkat kepatuhan pasien DM tipe 2 yang paling banyak jumlahnya di Puskesmas Kecamatan Makasar Jakarta Timur adalah kepatuhan dengan kategori sedang. Faktor bosan menjadi penyabab yang paling dominan sebagai penyebab ketidakpatuhan responden. Terdapat hubungan yang bermakna antara kepatuhan dengan kontrol kadar gula darah yang berarti bahwa pasien dengan kepatuhan yang tinggi akan berkaitan dengan terkontrolnya kadar gula darah mereka.

\section{DAFTAR PUSTAKA}

Adisa, R., Fakeye, T. O., \& Fasanmade, A. (2011). Medication adherence among ambulatory patients with type 2 diabetes in a tertiary healthcare setting in Southwestern Nigeria. Pharmacy Practice, 9(2), 72-81. https://doi.org/10.4321/s1886-36552011000200003

Alajmi, R., Al-Aqeel, S., \& Baz, S. (2017). The impact of a pharmacist-led educational interview on medication adherence of Saudi patients with epilepsy. Patient Preference and Adherence, 11, 959-964. https://doi.org/10.2147/PPA.S124028

Balkhi, B., Alwhaibi, M., Alqahtani, N., Alhawassi, T., Alshammari, T. M., Mahmoud, M., ... Kamal, K. M. (2019). Oral antidiabetic medication adherence and glycaemic control among patients with type 2 diabetes mellitus: A cross-sectional retrospective study in a tertiary hospital in Saudi Arabia. BMJ Open, 9(7), 1-11. https://doi.org/10.1136/bmjopen-2019-029280

Bulu, A., Wahyuni, T. D., \& Sutriningsih, A. (2019). Hubungan Antara Tingkat Kepatuhan Minum Obat Dengan Kadar Gula Darah Pada Pasien Diabetes Melitus Tipe II. Nursing News, 4(1), 181189.

Chawla, A., Chawla, R., \& Jaggi, S. (2016). Microvasular and macrovascular complications in diabetes mellitus: Distinct or continuum? Indian J Endocrinol Metab, 20(4), 546-551. 
Cohen, J. D., Aspry, K. E., Brown, A. S., Foody, J. M., Furman, R., Jacobson, T. A., ... Ito, M. K. (2013). Use of health information technology (HIT) to improve statin adherence and low-density lipoprotein cholesterol goal attainment in high-risk patients: Proceedings from a workshop. Journal of Clinical Lipidology, 7(6), 573-609. https://doi.org/10.1016/j.jacl.2013.10.002

Costa, E., Giardini, A., Savin, M., Menditto, E., Lehane, E., Laosa, O., ... Marengoni, A. (2015). Interventional tools to improve medication adherence: Review of literature. Patient Preference and Adherence, 9, 1303-1314. https://doi.org/10.2147/PPA.S87551

Dewanti, S. W., Andrajati, R., \& Supardi, S. (2015). Pengaruh konseling dan leaflet terhadap efikasi diri, kepatuhan minum obat, dan tekanan darah pasien hipertensi di dua puskesmas kota depok. Jurnal Kefarmasian Indonesia, 5(1), 33-40. https://doi.org/10.22435/jki.v5i1.4088.33-40

Hidajah R, M. R. (2012). PROFIL KEPATUHAN PENGGUNAAN OBAT HIPOGLIKEMIK ORAL GLIBENKLAMID (Pada Pasien Diabetes Mellitus Tipe 2 di Puskesmas Kedungkandang Malang). Farmasains: Jurnal Farmasi Dan Ilmu Kesehatan, 2(1). https://doi.org/10.22219/far.v2i1.1161

Kalyani, R. R., Golden, S. H., \& Cefalu, W. T. (2017). Diabetes and aging: Unique considerations and goals of care. Diabetes Care, 40(4), 440-443. https://doi.org/10.2337/dci17-0005

Kementerian Kesehatan RI. Standar Pelayanan Kefarmasian di Puskesmas (2016). indonesia.

Kementerian Kesehatan RI. (2018). Hasil Utama Riset Kesehata Dasar (RISKESDAS). Journal of Physics A: Mathematical and Theoretical, 44(8), 1-200. https://doi.org/10.1088/1751$8113 / 44 / 8 / 085201$

Lastra, G., Syed, S., Kurukulasuriya, L. R., Manrique, C., \& Sowers, J. R. (2014). Type 2 diabetes mellitus and hypertension: An update. Endocrinology and Metabolism Clinics of North America, 43(1), 103-122. https://doi.org/10.1016/j.ecl.2013.09.005

Morisky, D. E., Ang, A., Krousel-Wood, M., \& Ward, H. J. (2008). Predictive validity of a medication adherence measure in an outpatient setting. Journal of Clinical Hypertension, 10(5), 348-354. https://doi.org/10.1111/j.1751-7176.2008.07572.x

Mulyani, R. (2016). Hubungan Kepatuhan Dengan Keberhasilan Terapi Berbasis Kombinasi Insulin Dan Obat Antidiabetik Oral Pada Pasien Diabetes Melitus Tipe 2 Di Instalasi Rawat Jalan Rumah Sakit Umum Daerah Ulin Banjarmasin. Prosiding Rakernas Dan Pertemuan Ilmiah Tahunan Ikatan Apoteker Indonesia 2016, 116-122.

Nafi'ah, K. dkk. (2015). Profil Kepatuhan Pasien Puskesmas Pucang Sewu Surabaya dalam Penggunaan Antidiabetes Oral. Jurnal Farmasi Komunitas Universitas Airlangga, 2(1), 11-17.

Neswita, E., Almasdy, D., \& Harisman, H. (2016). Influence of Drug Counseling on Knowledge and Patient Compliance with Congestive Heart Failure. Jurnal Sains Farmasi \& Klinis, 2(2), 195302. Retrieved from http://jsfkonline.org/index.php/jsfk/article/view/61

Nyoman Wijaya, I., Faturrohmah, A., Yuda, A., Giovani Soesanto, T., Kartika, D., Wido Agustin, W., \& PNS Putri, H. (2015). Profil Penggunaan Obat Pada Pasien Diabetes Melitus Di Puskesmas Wilayah Surabaya Timur. Jurnal Farmasi Komunitas, 2(1), 23-28.

Radito, T. (2014). Analisis Pengaruh Kualitas Pelayanan Dan Fasilitas Kesehatan Terhadap Kepuasan Pasien Puskesmas. Jurnal Ilmu Manajemen, 11(2), 1-25. https://doi.org/10.21831/jim.v11i2.11753 
Rasdianah, N., Martodiharjo, S., Andayani, T. M., \& Hakim, L. (2016). The Description of Medication Adherence for Patients of Diabetes Mellitus Type 2 in Public Health Center Yogyakarta. Indonesian Journal of Clinical Pharmacy, 5(4), 249-257. https://doi.org/10.15416/ijcp.2016.5.4.249

Small, S. A. (2001). Age-Related Memory Decline. Archives of Neurology, 58(3), 360-364. https://doi.org/10.1001/archneur.58.3.360

Srikartika, V. M., Cahya, A. D., Suci, R., Hardiati, W., \& Srikartika, V. M. (2016). Analisis Faktor Yang Memengaruhi Kepatuhan Penggunaan Obat Pasien Diabetes Melitus Tipe 2. Jurnal Manajemen Dan Pelayananan Farmasi, 6(3), 205-212. https://doi.org/10.22146/jmpf.347

Willer, A. K., Herreiter, J., \& Pacini, G. (2016). Sex and Gender Differences in Risk, Pathophysiology and Complications of Type 2 Diabetes Mellitus. Endocrine Reviews, 37(3), 278-316. Retrieved from https://www.ncbi.nlm.nih.gov/pmc/articles/PMC4890267/\#

World Health Organiation. (2003). Adherence to long-term therapies: Evidence for action. World Health Organization (Vol. 1). https://doi.org/10.1016/S1474-5151(03)00091-4 